\title{
Review of Recommendations on Prophylactic Antibiotic Use in Cesarean Section -A Review Article
}

\author{
Minakshi Rohilla, Tanuja Muthyala*, Surbhi Aggarwal
}

Department of Obstetrics and Gynaecology, Post Graduate Institute of Medical Education and Research (PGIMER), Chandigarh, India

*Corresponding author: Tanuja Muthyala, Department of Obstetrics and Gynaecology, Post Graduate Institute of Medical Education and Research (PGIMER), Pin code: 160012, Chandigarh, India; E-mail: drtanujambbs@gmail.com

\begin{abstract}
The significant rise in Cesarean Section (CS) rates in both developing as well as developed countries mandates a definitive protocol for preoperative preparation, intra-operative surgical principles and postoperative care. Apart from surgical and anesthesia related complications, post-operative infections following a CS can lead to puerperal sepsis, near-miss maternal morbidity and mortality. Post cesarean section infections are likely to become a health and economic burden and their prevention remains a public health priority. One such preventive measure is appropriate and timely use of antibiotics in both elective and emergency cesarean sections. The infections are usually poly-microbial, involving aerobic and anaerobic organisms. Role of antibiotic prophylaxis in CS is clearly demonstrated in various studies, but the dosage and the ideal drug, its timing and frequency still remains debatable and controversy.This article reviews on various studies in the recent past regarding recommendations on prophylactic antibiotic use in cesarean section.
\end{abstract}

\section{Introduction}

Women who deliver by Cesarean Section [CS] are 5-20 times more predisposed to postpartum infections including endometritis, urinary tract infections, surgical site infections than women who deliver vaginally ${ }^{[1,2]}$. The incidence of infection varies widely from $2.5 \%$ to $20.5 \%$ and 40 to $75 \%$ in developed countries and developing countries respectively. With antibiotic prophylaxis, the post cesarean infectious morbidity was reduced in both in high risk and low risk patients ${ }^{[3]}$. The infection rate was reduced by half and more from a very high baseline of 20 $-50 \% 0^{[4,5]}$.

Organisms of the lower genital tract are common source of infection, and the risk is higher with ruptured membranes or with a preterm birth. Anaerobes and gram negative aerobes like species of Escherichia coli, Enterobacter, Klebsiella, Proteus and anaerobes like Bacteroides, Clostridium, and Fusobacterium are the common isolates ${ }^{[6]}$. Skin contaminants like Staphylococcus aureus may be isolated as a result of an interruption in the sterility, in the surgical technique, especially following an emergency or complicated surgery.

The need for antibiotic prophylaxis, the type and route of drug including timing and frequency, the cost-effectiveness, effects of antibiotics on the mother-child dyad and the development of antimicrobial resistance remains a major concern. Considering the fact that, surgical site infections are preventable but prevention is complex requiring integration of preoperative, in- tra-operative and postoperative events. The rates of surgical site infection especially in the presence of other risk factors like anemia, CS in labor, woman on immunosuppressive therapy may be decreased with effective antibiotic usage. Moreover, neonatal survival is best when there is no maternal jeopardy. Till date there is no evidence based global guidelines regarding choice of antibiotic, epidemiological data including bacteriology and sensitivity patterns of these infections, especially in resource limited countries so as to identify an ideal drug. A cost effective prophylactic antibiotic regimen with safe maternal and neonatal outcomes should be sought. Here in this review we discussed the recommendations by various organizations and randomized controlled studies (Table 1) over the period of time.

\section{Received date: January 18, 2018 \\ Accepted date: June 25, 2018 \\ Published date: July 1, 2018}

Citation: Muthyala, T., et al. Review of Recommendations on Prophylactic Antibiotic Use in Cesarean Section-A Review Article. (2018) J Gynecol Neonatal Biol 4(1): 18- 21.

Copyright: (C) 2018 Muthyala, T. This is an Open access article distributed under the terms of Creative Commons Attribution 4.0 International License. 
Table 1: RCTon antibiotic usage in cesarean section

\begin{tabular}{|c|c|c|c|}
\hline YEAR & STUDY BY & TYPE OF STUDY & OUTCOME \\
\hline 1991 & $\begin{array}{l}\text { Ruiz- More- } \\
\text { no et al- }{ }^{[8]}\end{array}$ & $\begin{array}{l}\text { RCT comparing i.v. } \\
\text { metronidazole vs pla- } \\
\text { cebo }\end{array}$ & $\begin{array}{l}\text { Endometritis }(14 \% \text { vs } \\
30 \%) \text {, wound infec- } \\
\text { tion }(2 \% \text { vs } 8 \%) \text { are less } \\
\text { in metronidazole group } \\
\text { when compared to placebo } \\
\text { group. }\end{array}$ \\
\hline 2001 & Pitt et al- ${ }^{[19]}$ & $\begin{array}{l}\text { Double blinded RCT } \\
\text { comparing intravagi- } \\
\text { nal metronidazole vs } \\
\text { placebo }\end{array}$ & $\begin{array}{l}7 \% \text { developed endometri- } \\
\text { tis in metronidazole group } \\
\text { as compared to } 19 \% \text { of } \\
\text { those receiving placebo } \\
\text { gel. }\end{array}$ \\
\hline 2003 & $\begin{array}{l}\text { Andrews et } \\
\text { al- }{ }^{[20]}\end{array}$ & $\begin{array}{l}\text { Double blinded RCT } \\
\text { comparing cefotetan } \\
\text { with doxycycline+ azi- } \\
\text { thromycin }\end{array}$ & $\begin{array}{l}\text { Post CS endometritis } \\
(16.9 \% \text { vs } 24.7 \%, p=.02) \text {, } \\
\text { wound infections( } 0.8 \% \\
\text { vs } 3.6 \% \text { and } p=.03) \text { were } \\
\text { significantly less in dox- } \\
\text { ycycline +azithromycin } \\
\text { group. }\end{array}$ \\
\hline 2003 & $\begin{array}{l}\text { Mayer et al- } \\
\text { [21] }\end{array}$ & $\begin{array}{l}\text { Double blinded pro- } \\
\text { spective RCT compar- } \\
\text { ing cefazolin versus } \\
\text { cefazolin plus metrani- } \\
\text { dazole }\end{array}$ & $\begin{array}{l}\text { Significant reduction } \\
\text { in postoperative infec- } \\
\text { tion rate }(14 \% \text { vs } 32 \%) \\
\text { and duration of hospital } \\
\text { stay }(3.12 \% \text { vs } 4.46 \%) \\
\text { with cefazolin plus metro- } \\
\text { nidazole group }\end{array}$ \\
\hline 2008 & $\begin{array}{l}\text { Alekwe et } \\
\text { al_- }^{[22]}\end{array}$ & $\begin{array}{l}\text { RCT comparing single } \\
\text { dose of ceftriaxone vs } \\
\text { multiple doses of am- } \\
\text { piclox, gentamycin, } \\
\text { metronidazole. }\end{array}$ & $\begin{array}{l}\text { Incidence of endometritis } \\
(14 \% \text { vs } 15 \%) \text {, UTI( } 11 \% \\
\text { vs } 15 \%) \text { and SSI( } 7 \% \text { vs } \\
6 \%) \text { are not significant- } \\
\text { ly different in both the } \\
\text { groups. }\end{array}$ \\
\hline 2009 & Tita et al- ${ }^{[14]}$ & $\begin{array}{l}\text { RCT comparing } \\
\text { i.v.azithromycin vs } \\
\text { placebo }\end{array}$ & $\begin{array}{l}\text { Infectious morbidity }(6.1 \% \\
\text { vs } 12 \%, \mathrm{p}<0.001), \text { endo- } \\
\text { metritis is }(3.8 \% \text { vs } 6.1 \% \text {, } \\
\mathrm{p}=0.002), \text { wound infec- } \\
\text { tion is }(2.4 \% \text { vs } 6.6 \%, \mathrm{p}< \\
0.001), \text { adverse maternal } \\
\text { events is }(1.5 \% \text { vs } 2.9 \% \text {, } \\
\mathrm{p}=0.03) \text { are significant- } \\
\text { ly less in azithromycin } \\
\text { group. }\end{array}$ \\
\hline 2013 & $\begin{array}{l}\text { Lyimo et al- } \\
\text { [23] }\end{array}$ & $\begin{array}{l}\text { RCT comparing single } \\
\text { i.v. dose of gentamy- } \\
\text { cin }+ \text { metronidazole vs } \\
8 \text { hrly administration } \\
\text { of the same antibiotics } \\
\text { for } 24 \text { hrs. }\end{array}$ & $\begin{array}{l}\text { SSI occurred in } 4.8 \% \text { in } \\
1 \text { st group compared to } \\
6.4 \% \text { in } 2 \text { ndgroup. }\end{array}$ \\
\hline 2017 & $\begin{array}{l}U \text { p } \mathrm{T} \text { o } \\
\text { Date }^{[24]}\end{array}$ & 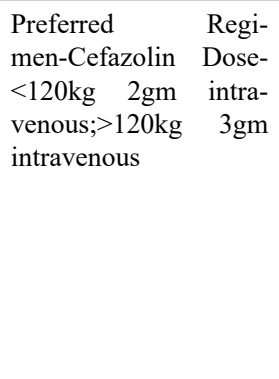 & $\begin{array}{l}\text { Alternative regimens-i) } \\
\text { Ampicillin-sulbactam } \\
3 \mathrm{gm} \text { intravenous ii) clin- } \\
\text { damycin } 600-900 \mathrm{mg} \text { in- } \\
\text { travenous or vancomycin } \\
15 \mathrm{mg} / \mathrm{kg} \text { plus one of the } \\
\text { following gentamycin } 5 \\
\mathrm{mg} / \mathrm{kg} \text { or aztreonam } 3 \mathrm{gm} \\
\text { iv iii) Metronidazole } 500 \\
\mathrm{mg} \mathrm{i.v} \mathrm{plus} \mathrm{gentamycin} 5 \\
\mathrm{mg} / \mathrm{kg}\end{array}$ \\
\hline
\end{tabular}

\section{Discussion}

In Cochrane review (2014) of 95 studies enrolling more than 15,000 women, the use of prophylactic antibiotics in woman who underwent CS reduced the incidence of wound infection (RR $0.40,95 \%$ CI 0.35 to $0.46,82$ studies, 14,407 women), en- dometritis (RR $0.38,95 \%$ CI 0.34 to $0.42,83$ studies, 13,548 women) and maternal serious infectious complications (RR $0.31,95 \%$ CI 0.20 to $0.49,32$ studies, 6159 women) when compared with no treatment. Gerstner, et al (1980) and Ruiz-Moreno, et al (1991) showed that when metronidazole was given intravenously, the chances of endometritis, surgical site infection, and rate of postoperative febrile morbidity was reduced ${ }^{[7]}$. In a prospective comparative study by O'Leary et al in 1986, post cesarean morbidity was lesser in ampicillin-gentamycin group as compared to ampicillin alone ${ }^{[8,9]}$. Metronidazole, when used as a prophylactic agent administered intravenously or rectally gave mixed results for post caesarean endometritis and wound infection. The timing of administration of antibiotic was also a concern. Cochrane (2002) and ACOG (2003) recommended administering prophylactic antibiotics after cord clamping ${ }^{[10]}$. Cochrane Database of Systematic Reviews (2003) and CDC (2006) recommended administration of cephalosporins of first generation like cefazolin after clamping of umbilical cord as prophylaxis against post- caesarean infections rather than a pre-surgical prophylaxis. Cefazolin was considered as it was equally effective and cheaper than broad-spectrum antibiotics ${ }^{[3,5]}$. A retrospective study conducted in Pittsburgh, USA (2002 - 2007), reviewed the cases of cesarean deliveries where antibiotic was given before the skin incision in first group and after clamping of cord in second group. First group had lower rates of endometritis and wound infection. Further, it had no adverse effect on the neonate. Similar findings were observed by Yokoe in $2001^{[10]}$ and Sullivan, et al (2008) when cefazolin was given 15-60 minutes preceding an incision or at the time of clamping of cord with no increase in rates of neonatal sepsis.

A questionnaire based study published in Journal of Indian Medical Association (2008) evaluated the antibiotic prescriptions of obstetricians working in different centers in Delhi, (India) in vaginal deliveries (episiotomies) and cesarean sections. A single antibiotic cefazolin 1 gm every $12^{\text {th }}$ hourly intravenously for three days was used by $34.4 \%$ and $33.3 \%$ of practitioners in planned and non-elective cesarean sections respectively. The antibiotic was used for five days by $35.5 \%$ and $41.1 \%$ doctors respectively. A triple antibiotic regimen of ampicillin, metronidazole and gentamycin was used by $30 \%$ and $25.5 \%$ doctors for planned and non-elective and Cesarean respectively for five days.

ACOG (2010) recommended cefazolin 1 - 2 g IV one hour prior to the surgery or as soon as possible if it is an emergency cesarean ${ }^{[11]}$. SOGC (2010) recommended, all parturient scheduled to elective or emergency CS should be given antibiotic as prophylaxis not more than 60 minutes prior to skin incision with first-generation cephalosporin and single drug dose is sufficient if total duration of surgery is less than three hours and the total blood loss is less than one and half liter when a repeat dose is advised. In case of allergy to penicillin, clindamycin or erythromycin can be used ${ }^{[12]}$.

Baaqeel, H and Baaqeel, R in 2013 systematic review regarding the timing of administration of prophylactic antibiotics in CS confirmed that the pre-incisional use and not after cord clamping, had less post CS maternal infectious morbidity and no immediate untoward effects on the newborn ${ }^{[13]}$. A RCT by Tita, et al in 2013 assigned women with a singleton pregnancy of $\geq$ 24 weeks period of gestation undergoing CS in labor with or 
Citation: Muthyala, T., et al. Review of Recommendations on Prophylactic Antibiotic Use in Cesarean Section-A Review Article. (2018) J Gynecol Neonatal Biol 4(1): 18- 21 .

without leakage of amniotic fluid to azithromycin plus standard antibiotic versus placebo versus standard antibiotic groups. Incidence of endometritis, wound complications, and serious maternal adverse events were significantly lower in azithromycin added group. The neonatal outcome was same in both the groups ${ }^{[14]}$. Systematic review of Cochrane database (2014) of 7299 women provided a comparison between the use of cephalosporins versus penicillin's for antibiotic prophylaxis for $\mathrm{CS}^{[15]}$. The efficacy of cephalosporins and penicillin's was comparable in preventing immediate post cesarean infections.

Pinto-Lopes R et al in 2017 in his review article included 16 studies, involving 2695 women and no significant difference was observed between single dose and multiple dose antibiotic prophylaxis in the incidence of postpartum infectious morbidity,endometritis, and wound infection. A trend towards lower risk of urinary tract infection was seen with multiple dosing $^{[16]}$.

Cefazolin belongs to first generation of cephalosporin and is a Category B drug in pregnancy. Its $t 1 / 2$ is 1.8 hours. Coverage for gram positive organisms including mycoplasma and urea plasma is good and modest for gram negative organisms. The concern with its use was an increase in the resistant strains of anaerobes which may be dealt with adding metronidazole, clindamycin, or azithromycin. Many center's now practice a single dose of $2 \mathrm{gm}$ cefazolin for all women undergoing CS as a standard regime. The higher dose of cefazolin 3 grams for obese women is supported by a study in which $\geq 20$ percent of obese when body mass index is 30 to $39.9 \mathrm{~kg} / \mathrm{m}^{2}$ and extremely obese women with body mass index of $\geq 40 \mathrm{~kg} / \mathrm{m}^{2}$ did not achieve therapeutic levels for Gram-negative rods with a $2 \mathrm{gm}$ dose. Despite these recommendations, there is ongoing debate concerning the use of more effective prophylaxis with newer and extended-spectrum drugs like cefotetan as endometritis is predominately a polymicrobial infection. The woman with high risk of postoperative infection like CS in labor or had ruptured membranes for more than four hours may benefit from an extended-spectrum regimen, but available data do not mandate a change in practice at this time.

Thus, as per recommendations, the duration of antibiotics usage in caesarean section has been reduced from more than 5 days to a single dose. But the older practice of multiple doses of antibiotics is still lingering on with a potential for development of antimicrobial resistance and harmful sequalae in the near future.

A survey (2005) of SEA-ORCHID project team in South East Asia on reviewing the medical reports of 9550 and found that antibiotic prophylaxis for CS was administered over more than one dose pre-orpost-operatively in majority ${ }^{[17]}$.

The goal of antibiotic therapy is to achieve sufficient tissue levels at the time of microbial contamination, and the ideal drug should be long acting, inexpensive, and have a low side effect profile. The wrong choice of antibiotic may result in the neonate being exposed to resistant strains of bacteria which may lead to a worse neonatal outcome and/or the need for extensive neonatal septic screens and infection work-ups. The confounding factors leading to difficulty in implementing a universal approach to antibiotic prophylaxis are complex and need to be studied. Moreover, the existing differences in the socio-economic status of the patients, feasibility and utilization of health resources in developing and developed world may lead to difficulty in having a universal regimen of antibiotic prophylaxis. Though single dose cefazolin has been recommended by various bodies for pre-surgical prophylaxis in CS, data on efficacy of a single drug as antibiotic prophylaxis is limited in developing countries and use of multiple drug regimens may evolve over time considering the high rates of post-cesarean morbidity in third world countries. Further knowledge of antibiotic susceptibility and resistant strains is to be considered. In a prospective study to evaluate the clinical profile and bacterial isolates among women with puerperal sepsis in a tertiary hospital in North India by Jayasree Vankuru et al, E. coli was the commonest pathogen isolated and was uniformly sensitive to amikacin which may be included among the initial antibiotics to treat puerperal sepsis in India $^{[18]}$. More randomized trials targeting these population should be done so as to globally recommend an ideal antibiotic.

\section{References}

1. Llu, S., Liston, R.M., Joseph, K.S., et al. Maternal mortality and severe morbidity associated with low-risk planned caesarean delivery versus planned vaginal delivery at delivery at term. (2007) CMAJ 176(4): 455-460.

Pubmed | Crossref | Others

2. Burrows, L.J., Meyn, L.A., Weber, A.M. Maternal morbidity associated with vaginal versus caesarean delivery. (2004) Obstet Gynaecol 103: 907-912.

Pubmed | Crossref $\mid$ Others

3. Smaill, F., Hofmeyr, G.J. Antibiotic prophylaxis for caesarean section. (2002) Cochrane Database Syst Rev 3: CD000933.

Pubmed | Crossref $\mid$ Others

4. Chelmow, D., Ruehli, M.S., Huang, E. Prophylactic use of antibiotics for non- laboring patients undergoing cesarean delivery with intact membranes: a meta- analysis. (2001) Am J Obstet Gynecol 184(4): 656-661. Pubmed | Crossref $\mid$ Others

5. Dinsmoor, M.J., Gilbert, S., Landon, M.B., et al. Perioperative antibiotic prophylaxis for non- labouring caesarean delivery. (2009) Obstet Gynecol 114(4): 752-756. Pubmed | Crossref | Others

6. Arianpour, N., Safari, A., Hatami, F. Bacteria isolated from postpartum infection. (2009) J Fam Reprod Health 3: 63-66. Pubmed | Crossref $\mid$ Others

7. Gerstner, G., Kofler, E., Huber, J. Perioperative metronidazole prophylaxis for cesarean section. (1980) Z Geburtshilfe Perinatol 184(6): $418-423$.

Pubmed | Crossref $\mid$ Others

8. Ruiz-Moreno, J.A., Garcia-Rojas, J.M., Lozada-Leon, J.D. Prevention of postcesarean infectious morbidity with a sin- 
gle dose of intravenous metronidazole. (1991) Int J Gynaecol Obstet 34(3): 217-220.

Pubmed | Crossref | Others

9. O’Leary, J.A., Mullins, J.H. Jr., Andrinopoulos, G.C. Ampicillin vs ampicillin- gentamicin prophylaxis at caesarean section. (1986) J Reprod Med 31(1): 27-30.

Pubmed | Crossref $\mid$ Others

10. Yokoe, D.S., Christiansen, C.L., Johnson, R., et al. Epidemiology of and surveillance for postpartum infections. (2001) Emerg Infect Dis 7(5): 837-841.

Pubmed | Crossref | Others

11. ACOG: Committee opinion no. 465: Antimicrobial prophylaxis for caesarean delivery. Timing of administration. (2010) Obstet Gynecol 116(3): 791-792.

Pubmed | Crossref | Others

12. van Schalkwyk, J., Van Eyk, N. Antibiotic prophylaxis in obstetric procedures. (2010) J Obstet Gynaecol Can 32(9):878-884.

Pubmed | Crossref | Others

13. Baaqeel, H., Baaqeel, R. Timing of administration of prophylactic antibiotics for caesarean section: a systematic review and meta-analysis. (2013) BJOG 120: 661-669.

Pubmed | Crossref | Others

14. Tita, A.T., Rouse, D.J., Blackwell, S., et al. Emerging concepts in antibiotic prophylaxis for caesarean delivery: A systematic review. (2009) Obstet Gynecol 113: 675-682. Pubmed | Crossref | Others

15. Gyte, G.M., Dou, L., Varquz, C. Different classes of antibiotics given to women routinely for preventing infection at caesarean section. (2014) Cochrane Database Syst Rev 17(11): CD008726.

Pubmed | Crossref | Others

16. Pinto-Lopes, R., Sousa-pinto, B., Azevedo, L.F. Single dose versus multiple dose of antibiotic prophylaxis in caesarean section: a systematic review and meta-analysis. (2017) BJOG 124(4): 595-605.

Pubmed | Crossref | Others

17. Jayasree, V., Bagga, R., Tanuja, M., et al. A clinical and microbiological study of puerperal sepsis in atertiary care hospital in India. (2018) J Maternal-fetal Neonatal Med 7: 1-7 Pubmed | Crossref | Others

18. Mitt, P., Lang, K., Peri, A., et al. Surgical-site infections following caesarean section in an Estonian university hospital: post discharge surveillance and analysis of risk factors. (2005) Infect Control Hosp Epidemiol 26(5): 449-54. Pubmed | Crossref | Others

19. Pitt, C., Sanchez-Ramos, L., Kaunitz, A.M. Adjunctive intravaginal metronidazole for the prevention of post cesarean endometritis: a randomized contol trial. (2001) Obstet Gynecol 98(5): 745-750.

Pubmed | Crossref $\mid$ Others

20. Andrews, W.W., Hauth, J.C., Cliver, S.P., et al. Randomized clinical trial of extended spectrum antibiotic prophylaxis with coverage for Ureaplasmaurealyticum to reduce post-cesarean delivery endometritis. (2003) 101: 1183-189 Pubmed | Crossref $\mid$ Others

21. Meyer, N.L., Hosier, K.V., Scott, K., et al. Cefazolin versus cefazolin plus metronidazole for antibiotic prophylaxis at caesarean section. (2003) South Med J 96(10): 992-995. Pubmed | Crossref $\mid$ Others

22. Alekwe, L.O., Kuti, O., Orji, E.O., et al. Comparison of ceftriaxone versus triple drug regimen in the prevention of cesarean section infectious morbidities. (2008) J Matern Fetal Neonatal Med 21(9): 638-642.

Pubmed | Crossref | Others

23. Lyimo, F.M., Massinde, A.N., Kidenya, B.R., et al. Single dose of gentamicin in combination with metronidazole versus multiple doses for prevention of post-caesarean infection at Bugando Medical Centre in Mwanza, Tanzania: a randomized, equivalence, controlled trial. (2013) BMC Pregnancy Childbirth 13: 123

Pubmed | Crossref $\mid$ Others

24. Most Frequent Procedures Performed in U.S. Hospitals, 2010. Antibiotic prophylaxis in cesarean section. (2017). Pubmed | Crossref | Others

Submit your manuscript to Ommega Publishers and we will help you at every step:

- We accept pre-submission inquiries

- Our selector tool helps you to find the most relevant journal

- We provide round the clock customer support

- Convenient online submission

- Thorough peer review

- Inclusion in all major indexing services

- Maximum visibility for your research

Submit your manuscript at OMMEgA Publishers https://www.ommegaonline.org/submit-manuscript 